\title{
Research on Rural Talent Resources Development against the Background of Rural Revitalization
}

\section{- Taking Yongning Township, Wanyuan City as an Example}

\author{
Chunyan Zhou' ${ }^{1}$, Lin Tian ${ }^{2}$ \\ ${ }^{1}$ Personnel Department, Sichuan University of Arts and Science, Dazhou, China \\ ${ }^{2}$ School of Foreign Languages, Sichuan University of Arts and Science, Dazhou, China \\ Email: 47872614@qq.com
}

How to cite this paper: Zhou, C.Y. and Tian, L. (2018) Research on Rural Talent Resources Development against the Background of Rural Revitalization. Journal of Human Resource and Sustainability Studies, 6, 318-324.

https://doi.org/10.4236/jhrss.2018.64045

Received: November 27, 2018

Accepted: December 26, 2018

Published: December 29, 2018

Copyright $\odot 2018$ by authors and Scientific Research Publishing Inc. This work is licensed under the Creative Commons Attribution International License (CC BY 4.0).

http://creativecommons.org/licenses/by/4.0/

\begin{abstract}
The current paper has conducted an in-depth research to Yongning Township of Wanyuan City, a national-level poverty-stricken county in order to further know the prospects of talent revitalization in rural areas proposed during the 19th National Congress, to analyze the difficulties in its implementation, and to propose corresponding solutions to help the rural areas realize the human resources development. Through study, the problems in talents revitalization have been found by analyzing the current situation of talent resources and the requirement for talents in the area.
\end{abstract}

\section{Keywords}

Rural Revitalization Strategy, Talent Revitalization, Talent Resource Development

\section{Introduction}

President Xi Jinping put forward the strategy of rural revitalization in the report of the 19th National Congress of the Communist Party of China. The implementation of the strategy of rural revitalization should rely on the promotion of the revitalization of rural industries, rural talents, rural culture, rural ecology and rural organizations [1]. Among them, talent revitalization is the core of rural revitalization. Besides, the general secretary also emphasized talent as the first resource. To revitalize the countryside, we must first achieve "revitalization of talents" so that rural talents who are professional in rural agriculture, business, market and technology will have the stage and opportunities to develop their 
talents in an unlimited way. The rural revitalization strategy is an important strategy to promote national development, and the talents revitalization is of great significance for the realization of rural revitalization. On January 2, 2018, the state council issued the "Opinions on Implementing the Rural Revitalization Strategy". The opinions clarified the strengthening of rural grassroots basic work and the establishment of a new system of rural governance: to establish a long-term mechanism for the selection of first secretaries, and send first secretaries to work in poverty-stricken villages, the weak villages, and those villages with weak collective economy [2]; to optimize the quality of rural leaders, and attract university graduates, migrant workers, outstanding party members of government enterprises and institutions to serve in the village; to improve the system of recruiting township leading cadres, civil servants and staff of government affiliated institutions from the outstanding village party organizations. The implementation of the rural revitalization strategy requires the selection of a large number of cadres to work in the countryside. This is an important guarantee for the success of the rural revitalization strategy. In order to comprehensively understand the current situation of rural human resources in Dazhou and explore the bottlenecks restricting the development of rural human resources, we conducted field researches on Yongning Township of Wanyuan City, a national poverty-stricken area. Through research and analysis, we sought to explore the problems of rural talents revitalization.

\section{The Connotation of "Talents Revitalization"}

Talent revitalization is the top priority in order to achieve rural revitalization. Talents refer to those capable and high-quality laborers in human resources with certain professional knowledge or specialized skills, who are able to carry out creative work and contribute to the society. In the countryside, not everyone can be called a talent. At present, the majority of people staying in rural areas are old people. They generally just receive junior high school education, and some, however, are illiterate or only primary school graduates. Therefore, the skills mastered by some of the mduring their work outside the village cannot be regarded as expertise. The revitalization of the rural areas must first be supported by human resource, with which will it be possible to talk about the economic and cultural development. With the in-flow of talents, the village will have much more vigor and vitality. The rural areas need "three rural" work teams that know agriculture, love farmers and love villages. They also need talents who have agricultural technologies, management skills, and great abilities. Rural grassroots management needs to be achieved by talents with management capabilities, and the development of rural industrial economy needs to be led by those who know the economy and the market. If there are people who want to put themselves in the shoes of the farmers, think about rural development, and spare no effort in establishing a well-developed village, then these people surely love the countryside and the farmers. Because of love, they are willing to go to the countryside and stay to work there. In present rural areas, there is an urgent need for such a 
group of talents, who will display their talents as much as possible in the vast world of the countryside with their knowledge, technology and strengths. Talents revitalization is fundamentally to promote development with talents, to promote rural areas with talents, to enable talents to renew their vitality and potential in rural revitalization, and to make talents a powerful driving force for revitalizing the countryside.

\section{The Problems of Talents Revitalization in Rural Areas}

\subsection{A Great Loss of Talents and Labor Force}

With rapid economic development, the urban-rural gap is widening and urban area is superior to rural areas in economic conditions. Most rural young people are flowing into the city for higher wages, favorable promotion opportunities and better development prospects, leading to the increasing number of left-behind elders and the labor shortage in rural areas. In the rural areas, there are families who have college graduates, representing the hope of the family. It is also known from the actual investigation that there are also several college graduates each year who just grow up in the villages of Puziling Village and Tiefosi Village in Yongning Township, but few is willing to stay in the countryside for rural revitalization. Parents work hard their entire life, only hoping that their children will be able to walk out of the poor area one day rather than stay and work in the countryside. Therefore, most of the talents cultivated locally are out flowing, and the brain drain is greater than the introduction of talents, which further exacerbates the shortage of rural talents. As stated by Li Mingqing, secretary of Baishuba Village, "The greatest bottleneck in rural development is the massive loss of talents and labor force". The data shows that the village has a registered population of 745 people, among which only 237 still stay in the village, while up to $70 \%$ of them have already been out of the village for work. The situation of the entire township is also roughly the same.

\subsection{Lack of Reserve Talents for Village Cadres}

Village cadres are managers of all aspects of the village and are also leaders of a village. Therefore, they play significant roles in the development of a village. In the rural areas, villagers' self-governance is implemented, and the village cadres will be reelected over a certain period. Thus, capable reserve talents are needed. Village cadres should play a leading role, requiring that those reserve talents should have good qualities and are willing to devote themselves to rural development. However, rural grassroots work is heavy and complicated, and village cadres need to deal with the villagers from time to time. Sometimes, improper handling of some interest-related issues may arouse the contradictions between farmers and village cadres. The village cadres are dedicated to serving the villagers but they are misunderstood, which makes some people believe it "troublesome work". Therefore, most people are reluctant to serve as village cadres. According to the survey, there are almost no university-graduate village officials in this area, only a few institutional township and village staff. At present, much of 
the work is basically done by the cadres who temporarily work in the village for poverty alleviation. The lack of reserve talents for village cadres is a problem that cannot be ignored, and which needs to be resolved with immediate measures. Otherwise, the countryside will be encountered with a crisis.

\subsection{Lack of Industry Development Leaders}

Industries are necessary for rapid rural economic development, and some people are needed to take the lead in promoting the budding of an industry. Whether an industry is suitable for development in a specific area is only known when it is actually practiced. Farmers are mostly realist and tend to pursue directly visible benefits. If appropriate, more people are willing to develop the industry, and vice versa. However, "the first person to eat crabs" always bears a lot of risks. Once it fails, it costs not only human and material resources, but also its own confidence in the development of the industry. Moreover, the villagers have been accustomed to the planting of traditional crops with traditional agricultural technologies, and thus are not easy to change and accept new thing, which is obviously a great obstacle to promote new-type industrial development in rural areas. For the entire Yongning Township, the leaders leading the industry are insufficient. According to the data, there are only 2 companies in Yongning Township, and less than 10 rural leaders in making wealth with an average of less than two per village. In addition, the research reveals that some grassroots governments offer in sufficient support and funds for rural industrial development. For these reasons, the leaders of rural industry development are seriously lacking.

\subsection{Insufficient Teachers in All Aspects}

Every aspect of rural revitalization requires someone to take the lead, and in some cases, professional teachers are needed. For example, in terms of square dance in cultural revitalization, a teacher who is good at square dancing is needed to teach the villagers, but the current rural area lacks such teaching talents. The villager evening school also faces the shortage of teachers. Currently, those large-scale planters and poultry breeders share relevant knowledge to the villagers. However, they can only provide some referable measures for other villagers as experienced people not professionals. Hence, the villager evening school sometimes has to invite some experts from other areas to teach the villager some techniques for preventing crop pests and diseases. With regard to school education, there is only one primary school in Yongning Township with over ten teachers. All in all, the rural areas are lacking in teachers, either in teaching knowledge or teaching techniques.

\section{Reasons for Talents Revitalization Difficulties in Rural Areas}

\subsection{Poor Treatment of Rural Talents}

Many people are now reluctant to work in the countryside, and those who grow 
up in rural areas are also eager to go to the city for job hunting, because most of them believe there is no promising future to work in rural areas, either in terms of income or job promotion. As a farmer, his annual income is closely related with the weather condition. Only when there is no natural disaster in a year, will he have more income with a good harvest. There is almost no other channel for more revenue. If you work as a village cadre, the burden on your shoulders is very heavy, but there is no salary, only about a-thousand-yuan subsidies per month. After the village cadres have finished their village affairs, they have almost no time to take care of their own farm work. Hence, the village cadres often need to spend a lot of time and energy on the heavy and complicated grassroots work without equivalent payment. However, working in cities is different. Some enterprises will buy medical insurance, unemployment insurance, employment injury insurance, maternity insurance and public housing funds for their employees who can work free of worries. According to the grassroots cadres of the Yongle community, the current grassroots cadres have poor welfare and are even lack of social security. They work hard when they are young, but they do not have a life guarantee when they are old. The urban and rural cadres are not equally treated in terms of wages and welfares. Based on the current situation of rural economic development, the poor treatment of rural talents is temporarily unable to change, but we have to acknowledge that it is the primary reason that restricts talents to return home and work there.

\subsection{Limited Space for Rural Development}

There is little opportunity for job promotion and salary increase to a person who works in the countryside, while he is likely to be cultivated and promoted if he works in an urban enterprise and has a good performance. If he works in a university research institution, he will concentrate on his own research, gain achievements, honors, status, and even go abroad for further study. However, there is little chance to encounter with the new things in the countryside, which will limit their horizons. The industrial development environment is limited and the room for personal development is narrow. The rural area lacks communication with the outside world and does not receive important information such as emerging industries, technologies and market conditions. For individuals, there are far more opportunities to seek development in cities than in rural areas, and conditions are better than rural areas. Some villagers even believe that staying in the countryside limits the development of a person and has no future. It can be seen that for most people, the development space provided by the rural areas to individuals is too limited.

\subsection{Imperfect Rural Infrastructure}

Improving rural infrastructure and optimizing rural public services are important measures to boost rural development [3]. The countryside is now under construction. Although it has achieved a lot of development compared with previous years, many infrastructures are still not perfect, especially in medical and 
education. In terms of transportation, the majority rural areas have access to roads, which link these places conveniently. However, some areas are still faced with weak traffic conditions, which add much more difficulty for the villagers to go to the town. Therefore, it takes a long time to completely improve the construction of the transportation network. In terms of health care, there is a serious shortage of medical personnel, medical equipment, and pharmaceuticals. At present, most health clinics established in the rural areas are relatively simple. The villagers who have serious illnesses or thorny conditions must go to the urban hospitals for medical treatment. In terms of education, there are a small number of students in rural areas, because most of the children have followed their migrant parents to the places where they work and receive education there. Besides, the schools are mostly in the town with outdated teaching equipment and insufficient teachers. All these discouraging conditions become the barriers for those people who want to come to work in the countryside, and meanwhile the driving force for those who are already in the village to leave.

\subsection{Outdated Thoughts}

Nowadays, most people in rural areas think that there is no future to stay in the countryside. Only working in the city will win the neighbors' praise. It is difficult to develop a new industry in the countryside, because the farmers are not likely to accept the new planting techniques and support the new industry due to their low-level education and the influence of traditional thoughts. In the course of the field investigation, it was learned from Mr. Zhang, a gastrodiaelata grower in Tiefosi Village, that gastrodiaelata needs artificial pollination which is a new planting technique and thus not accepted by the villagers, so few farmers are willing to grow it. Therefore, even if the local climate is suitable for the growth of gastrodia, it is not likely to develop as a large-scale industry. Perhaps in the near future, the countryside will usher in a new look and farmers will accept new ideas, when Plants such as gastrodiaelata that need new planting technology will be accepted by the farmers and planted on a large scale so as to form a large-scale industry and promote the development of the rural economy.

\section{Conclusion}

In rural revitalization, rural grassroots talents can play a huge role in the entire social and economic development. The research learned about the problems of talents revitalization in the rural areas, and the reasons why it is difficult to achieve rural talents revitalization, providing enlightenments for further research on stimulating rural talents revitalization. It is expected to boost rural revitalization in Dazhou by making breakthroughs in the solutions of talent revitalization, such as talent treatment as suggested in the paper.

\section{Conflicts of Interest}

The authors declare no conflicts of interest regarding the publication of this paper. 


\section{References}

[1] Xi, J.P. (2017) Decisive Victory to Build a Moderately Prosperous Society in an All-Round Way and to Win a Great Victory in Socialism with Chinese Characteristics in the New Era. Xinhua News Agency, Oct. 27.

[2] CPC Central Committee State Council. (2018) Opinions on Implementing Rural Revitalization Strategy. Xinhua News Agency, Feb. 4.

[3] Wei, S.S. (2018) The Dilemma and Transformation of Rural Governance under the Background of Rural Revitalization. People's Forum, No. 2. 